\title{
Temporal and spatial patterns in waterborne bacterial communities of an island reef system
}

\author{
Michael J. Sweet ${ }^{1, *}$, Aldo Croquer ${ }^{1,2}$, John C. Bythell ${ }^{1}$ \\ ${ }^{1}$ School of Biology, Ridley Building, University of Newcastle, Newcastle upon Tyne NE1 7RU, UK \\ ${ }^{2}$ Universidad Simon Bolivar, Departamento de Estudios Ambientales, Apartado postal 89000, Caracas 1080, Venezuela
}

\begin{abstract}
The bacterial 16S rRNA gene diversity of waterborne bacterial (WBB) communities was assessed using PCR/denaturing gradient gel electrophoresis (DGGE) techniques, along with sequence analysis of selected bands. 16S rRNA gene diversity varied between seasons, and significant differences were recorded between night and day. However, there were no significant differences detected between low, ebb, flood and high tides when the water body sampled would have originated from completely different areas including those off-reef. These results suggest that changes in productivity and/or vertical diurnal migrations of plankton may have greater effects than large-scale water movements effected by tidal flows. These results do not demonstrate a strong link between WBB communities and their underlying benthos. This either suggests a lack of coupling between the benthos and the water column (benthic-pelagic coupling) or that the processes are extremely rapid and efficient with strong mixing. Previous studies at this site have shown cycling between coral reef and lagoon sediments via coral mucus release and tidal transport, supporting the latter. We found a strong seasonality in the abundance and composition of WBB communities, with Alphaproteobacteria being more prevalent during winter and Gammaproteobacteria during summer, but quantitative PCR (qPCR) showed no significant differences in vibrios between seasons.
\end{abstract}

KEY WORDS: Waterborne bacterial communities - Benthic-pelagic coupling • Bacterial fingerprinting $\cdot 16 \mathrm{~S} \mathrm{rDNA} \cdot \mathrm{DGGE}$

\section{INTRODUCTION}

Waterborne bacteria (WBB) in coral reef systems are very numerous and diverse, and their productivity is high compared to open oceanic waters (Sorokin 1973, 1974). Periodic influx of open water masses into coral reef lagoons is a process known to affect key ecological processes such as transport of nutrients (Naumann et al. 2009), delivery of dissolved and particulate organic matter (Crossland et al. 1984) and primary productivity (Moses et al. 2009); therefore, this influx should influence the dynamics of WBB communities. This hydrodynamic process is complex, being extremely variable in space and time, depending on depth, reef topography, position, the lunar cycle and time of the day, among other factors. However, culture and non-culture (molecular) approaches to assessing WBB communities in coral reef ecosystems, encompassing different spatial and temporal scales, are limited, with only a few lo- calised studies looking at changes associated with tidal cycles or seasonal change (Moriarty et al. 1985, Torreton \& Dufour 1996, Guppy \& Bythell 2006).

Coral reefs such as those studied here may release ca. $1.7 \mathrm{l}$ of mucus $\mathrm{m}^{-2} \mathrm{~d}^{-1}$ into the water column (Wild et al. 2004). More than half (56 to $80 \%$ ) of the released carbon is dissolved directly into the water column, providing a food source for planktonic bacteria (Wild et al. 2004). The less soluble fraction (20 to $44 \%$ ) forms mucus strands that detach from the coral branches, passing upwards through the water column and subsequently aggregating and accumulating at the surface. These are concentrated by currents and winds to form large (2 to $10 \mathrm{~m}$ ) 'mucus mats', trapping larger particles present within the water column. Continuous compaction and accumulation of re-suspended particles gradually decrease the buoyancy of these mats, and coupled with water movements of incoming tides, concentrate them towards the lagoon. Rapid sinking 
occurs at distances of over $150 \mathrm{~m}$ from the reef crest. The microbial communities of lagoon sands degrade this organic matter in the upper sediment layers through a natural filter system brought about by wave action and tide-induced differences in water level (Wild et al. 2004). Thus, under such 'benthic-pelagic coupling' (Wild et al. 2004), strong spatial differences in WBB would be expected between different water masses (reef crest, reef flat, lagoon water and off-reef water). Added to this, seasonal changes in waves, currents and organic matter deposition as well as benthic activities are thought to cause spatial and temporal variation in sediment-water exchange processes, affecting sedimentary organic carbon decomposition and $\mathrm{O}_{2}$ fluxes (Wild et al. 2009). These environmental changes in turn may also produce shifts in the WBB communities, mucus mats and sediment types over time and across sites.

Despite increasing interest in benthic-pelagic coupling in coral reefs (Wild et al. 2004, 2009, Naumann et al. 2009), baseline studies examining the spatial and temporal changes of bacteria within the water column and in particular its relation to the potential supply of bacteria to the coral's mucus are limited (Sunagawa et al. 2010). Previous attempts to compare the WBB communities based on discrete sampling (e.g. bottles, Paul et al. 1986; Sterivex filtration, Somerville et al. 1989; and syringe membrane filters, Guppy \& Bythell 2006) may not adequately address the highly variable spatial-temporal nature of these assemblages, which may underestimate the long-term delivery of microorganisms to a coral. Thus, this study aimed to provide a comprehensive measure of the bacterial diversity in the water column through space and time, by continually sampling over $1 \mathrm{~h}$ periods using a pump sampler. This enabled the inlet to be precisely positioned for greater accuracy and flow rates to be controlled to approximate natural delivery rates at environmentally relevant flow speeds (matched by the pump when in the field at the time of sample collection). In this study, we tested whether the composition of bacterial 16S rRNA gene diversity changed in relation to the influence of off-reef, open water masses and their relative position in the reef tract (i.e. lagoon, reef flat and reef front) and whether the structure of bacterial communities changed at different temporal scales (from diurnal variations and tidal cycles to seasonal shifts in diversity).

\section{MATERIALS AND METHODS}

Study area. The study was conducted at Heron Island, Great Barrier Reef (GBR), Australia (Fig. 1) over 2 yr (2008 to 2009), encompassing both a summer (March 2009) and winter (August 2008) season. A total of 5 sites (A-E) were assessed at high tide to estimate spatial variability in WBB communities. Tidal, diurnal and seasonal variability was evaluated at a single site (A) located on the reef flat (Fig. 1). These sites were chosen as they were expected to show variation in their bacterial diversity due to differences in the benthos and known oceanographic patterns around the island. For consistency, no spatial samples were taken when wind speeds were above $5 \mathrm{~m} \mathrm{~s}^{-1}$ (10 knots). Sites A, B, D and $\mathrm{E}$ were located in reef areas where delivery of water masses was from off-reef areas; thus, at the time of collection (high tide), all of these sites had received a strong influence of open waters (water depths $>30 \mathrm{~m}$ ), with currents flowing southwards. At flow speeds previously recorded on the reef flat of approximately $0.3 \mathrm{~m}$ $\mathrm{s}^{-1}$ (Gourlay \& Hacker 2008), this would mean that the water masses would have originated approximately $6 \mathrm{~km}$ offshore to the north during the previous low tide. Site A and, to a lesser extent, B would also have been influenced by strong mixing during passage of the water body over the shallow reef crest to the northwest within the last tidal cycle. Site $\mathrm{C}$ was located in the predominantly sandy lagoon system, where weaker currents and ponding (Ludington 1979) would mean that

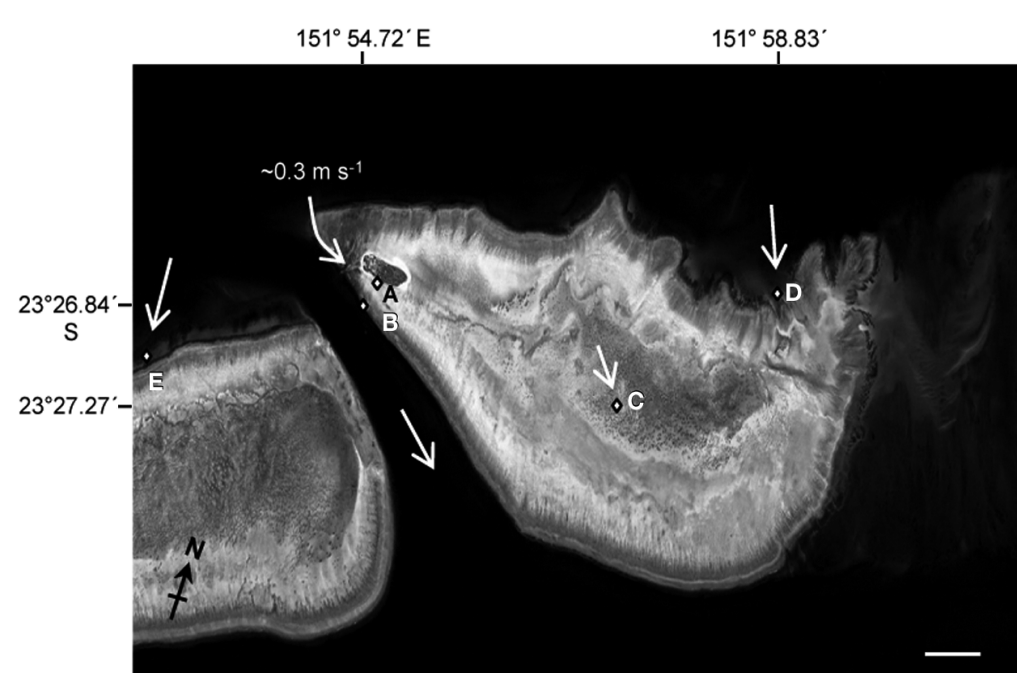

Fig. 1. Heron Island, Great Barrier Reef, Australia (23 $\left.27^{\prime} \mathrm{S}, 151^{\circ} 55^{\prime} \mathrm{E}\right)$. Location of main study site-Reef Flat (A) - and those used in spatial sampling: $\mathrm{B}$, Coral Gardens $\left(23^{\circ} 26.839^{\prime} \mathrm{S}, 151^{\circ} 54.717^{\prime} \mathrm{E}\right) ; \mathrm{C}, \mathrm{La}-$ goon $\left(23^{\circ} 27.272^{\prime} \mathrm{S}, 1^{\circ} 51^{\circ} 57.921^{\prime} \mathrm{E}\right) ; \mathrm{D}$, 3rd/4th Point $\left(23^{\circ} 26.146^{\prime} \mathrm{S}\right.$, $\left.151^{\circ} 58.833^{\prime} \mathrm{E}\right)$; E, Wistari $\left(23^{\circ} 29.081^{\prime} \mathrm{S}, 151^{\circ} 54.015^{\prime} \mathrm{E}\right)$. Arrows depict approximate direction of current flow on the flood tide, prior to sampling on the high tide. Samples were taken on calm days with wave speed $<0.5 \mathrm{~m} \mathrm{~s}^{-1}$ and wave heights $<0.5 \mathrm{~m}$. Scale bar $=1 \mathrm{~km}$ 
the water mass would likely have circulated locally, with minimal influence of off-reef open waters (Fig. 1).

Sample collection. Spatial variation: Spatial samples for both diversity and abundance were taken using discrete sterile 11 bottles, $5 \mathrm{~cm}$ above a colony of Acropora formosa. All samples were taken during both summer (March 2009) and winter (August 2008) within $1 \mathrm{~h}$ before high tide, over 2 consecutive days at a constant depth of $8 \mathrm{~m}$ (except for the lagoon and reef flat, where maximum depths were $2 \mathrm{~m}$ ). This ensured that the water masses being sampled were representative of different environments.

Temporal and diurnal variation: Samples to assess temporal changes in bacterial diversity were collected from Site A (Fig. 1) using a peristaltic pump (Masterflex E/S, Cole-Parmer) with internal battery source and polytetrafluoroethylene (PTFE) tubing. The tubing allowed positioning of the inflow to be accurate and permanently in place, anchored directly next to a colony of Acropora formosa, therefore giving an accurate representation of the WBB that a coral would be exposed to over the sampling period. All apparatus was placed within a tin boat anchored permanently offshore, allowing easy access day or night. This set-up enabled 11 of water surrounding the corals to be directly and continuously sampled onto $0.22 \mu \mathrm{m}$ Sterivex filters. The sampling system filtered water continuously for a period of $1 \mathrm{~h}$. Samples were collected every $2 \mathrm{~h}$ within a $24 \mathrm{~h}$ period. This sampling regime was duplicated within a period of $14 \mathrm{~d}$ and repeated over $2 \mathrm{yr}$, encompassing both summer and winter seasons. The sampling was timed to encompass $30 \mathrm{~min}$ on either side of high, mid- and low tides. In this way, both diurnal and tidal (high, low, ebb and flood) effects on bacterial abundance and diversity could be assessed along with seasonal effects. Bacterial communities were simultaneously sampled using discrete bottle samples and the pump sampler for method comparison.

Samples for analysis of bacterial abundances were collected with discrete bottles, similar to that of the spatial samples and at the same time as the temporal, diurnal and tidal samples on the fore reef; from this initial $1 \mathrm{l}$ sample, a volume of $15 \mathrm{ml}$ was vacuum-filtered through a $0.22 \mu \mathrm{m}$ black polycarbonate filter immediately after collection and fixed with $100 \mu \mathrm{l}$ of $4 \%$ PBS buffered paraformaldehyde solution until analysis (Fuhrman et al. 2008). In total, 3 replicates were taken at every sample period both for bacterial diversity and abundance regardless of the method. Hobo ${ }^{\circledR}$ (Onset Computer Corporation) temperature data loggers were deployed to record the temperature fluctuation at all sites.

Total bacterial abundance. To estimate bacterial abundances, each sample was stained with $100 \mu \mathrm{l}$ of $4 \%$ PBS buffered paraformaldehyde solution containing 4'6-diamidino-2-phenylindole (final concentration
$5 \mu \mathrm{g} \mathrm{ml}^{-1}$ ) for $10 \mathrm{~min}$, rinsed with filtered $1 \times \mathrm{PBS} \mathrm{pH}$ 7.4 (Yu et al. 1995, Weinbauer et al. 1998, Yamaguchi et al. 2007) and viewed under epifluorescence microscopy. Counts on 50 fields of view were taken, scaled up to the total area of the filter and calculated to give total bacterial abundance $\mathrm{ml}^{-1}$ of sea water filtered. An average of the 3 replicates was taken and used in further analysis.

Bacterial diversity, DNA extraction, amplification and denaturing gradient gel electrophoresis (DGGE) analysis. DNA was extracted from the filters using QIAGEN DNeasy Blood and Tissue kits with an added step to concentrate the lysate using vacuum centrifugation for $2 \mathrm{~h}$ at $20^{\circ} \mathrm{C}$. Bacterial 16S rRNA was amplified using standard prokaryotic 357F (5'-CCT ACG GGA GGC AGC AG- 3') and 518R (5'-ATT ACC GCG GCT GCT GG-3') primers. These primers were chosen over more traditional ones as they have been recently shown (Sanchez et al. 2007) to more comprehensively amplify marine bacteria compared to inadequacies and mismatches caused by those such as $907 \mathrm{r}$ (pC) (Muyzer et al. 1993, Guppy \& Bythell 2006, Sanchez et al. 2007). The GC-rich sequence 5'-CGC CCG CCG CGC GCG GCG GGC GGG GCG GGG GCA GCA CGG GGG G-3' was incorporated in the forward primer 357 at its $5^{\prime}$ end to prevent complete disassociation of the DNA fragments during DGGE. Thirty PCR cycles were performed at $94^{\circ} \mathrm{C}$ for $30 \mathrm{~s}, 53^{\circ} \mathrm{C}$ for $30 \mathrm{~s}$ and $72^{\circ} \mathrm{C}$ for $1 \mathrm{~min}$ and a final extension at $72^{\circ} \mathrm{C}$ for 10 min (Sanchez et al. 2007). A $30 \mu l$ PCR reaction was used containing $1.5 \mathrm{mM} \mathrm{MgCl} 2,0.2 \mathrm{mM}$ dNTP (PROMEGA), bovine serum albumin (BSA, $400 \mathrm{ng}$ $\left.\mathrm{\mu l}^{-1}\right), 0.5 \mathrm{mM}$ of each primer, $2.5 \mathrm{U}$ of Taq DNA polymerase (QBiogene), incubation buffer, and $20 \mathrm{ng}$ of template DNA (Siboni et al. 2007). All reactions were performed using a Hybaid PCR Express thermal cycler. PCR products were verified by agarose gel electrophoresis $(1.6 \%[\mathrm{w} / \mathrm{v}]$ agarose) with ethidium bromide staining and visualised using a UV transilluminator.

DGGE was performed using the D-Code universal mutation detection system (Bio-Rad). PCR products were resolved on $10 \%(\mathrm{w} / \mathrm{v})$ polyacrylamide gels that contained a 30 to $60 \%$ denaturant gradient for $13 \mathrm{~h}$ at $60^{\circ} \mathrm{C}$ and a constant voltage of $50 \mathrm{~V}$. Gels were stained with a concentrated solution of $9 \mu \mathrm{LSYBR}{ }^{\circledR}$ Gold (Sigma) in $50 \mu \mathrm{l}$ of $1 \times \mathrm{TAE}$ poured directly onto the gel surface, covered and left in the dark for 20 min then further washed in $500 \mathrm{ml} 1 \times \mathrm{TAE}$ for $30 \mathrm{~min}$ and visualised using a UV transilluminator. Bands of interest (those which explained the greatest differences/similarities between samples) were excised from DGGE gels, left overnight in Sigma molecular grade water, vacuum centrifuged, re-amplified with primers $357 \mathrm{~F}$ and 518R, labelled using a Big Dye (Applied Biosys- 
tems) transformation sequence kit and sent to Genevision (University of Newcastle) for sequencing. Bacterial operational taxonomic units (OTUs; Guppy \& Bythell 2006) were defined from DGGE band-matching analysis using BioNumerics 3.5 (Applied Maths BVBA). Standard internal marker lanes were used to allow for gel-to-gel comparisons. Tolerance and optimisation for band-matching was set at $1 \%$.

Real-time PCR (qPCR) was conducted on an Engine Opticon ${ }^{\circledR} 2$ system in order to test whether Vibrio spp. abundance changed between seasons. For this, Vibriospecific primers 567F (5'-GGC GTA AAG CGC ATG CAG GT-3') and 680R (5'-GAA ATT CTA CCC CCC TCT ACAG-3') (Thompson et al. 2004) were used on 10 randomly chosen samples from both the summer and winter seasons. This primer pair has previously been shown to be highly targeted towards vibrios, matching 42 out of 43 sequences of Vibrio-type strains in the Ribosomal Database Project (RDP) database (Thompson et al. 2004). Real-time PCR reaction mixtures totalled $25 \mu \mathrm{l}$ and consisted of $12.5 \mu \mathrm{l}$ of $2 \times$ Quantitect ${ }^{\circledR}$ SYBR ${ }^{\circledR}$ Green 1 supermix (Qiagen), $1.25 \mu \mathrm{l}$ each of $0.5 \mathrm{mM}$ forward and reverse primers, $50 \mathrm{ng}$ DNA and $9.5 \mu$ l Sigma molecular grade water. Each set of samples included a negative control, in which water was substituted for the DNA sample. Real-time PCR was performed with an initial activation step of $15 \mathrm{~min}$ at $95^{\circ} \mathrm{C}$, followed by 39 cycles $\left(94^{\circ} \mathrm{C}\right.$ for $15 \mathrm{~s}, 58^{\circ} \mathrm{C}$ for $30 \mathrm{~s}$, primer annealing at $58^{\circ} \mathrm{C}$ for $30 \mathrm{~s}$ ). The fluorescent product was detected after each extension. Following amplification, melting temperature analysis of PCR products was performed to determine the specificity of the PCR. The melting curves were obtained by slow heating at $0.5^{\circ} \mathrm{C} \mathrm{s}^{-1}$ increments from 50 to $90^{\circ} \mathrm{C}$, with continuous fluorescence recording.

Statistical analysis. For bacterial counts, an automatic cell counter (Cell C) was used (Selinummi et al. 2005). The parameters were set to exclude any objects smaller than $0.0314{\mu m^{2}}^{2}$ and anything larger than $0.7 \mu^{2}$. The abundance of bacteria was compared across sites and between seasons, time of day and tidal state with a 1-way and a 3-way analysis of variance (ANOVA), respectively. Data were normally distributed and variances were equal. In order to assess spatial and temporal changes in bacterial assemblages, matrices consisting of OTUs and samples were generated using both presence/absence and band intensity data, using marker lanes for between-gel comparisons. Spatial changes in WBB assemblages were evaluated with a 1-way analysis of similarity (ANOSIM, Primer) and multidimensional scaling (MDS), based on BrayCurtis similarities, which was performed on both summer and winter data sets. Methods of collection (those sampled only during August 2008) were compared by a 1-way ANOSIM (Primer).
For temporal comparisons, a 3-way multivariate permutation ANOVA (PERMANOVA; Primer) based on Bray-Curtis distance (Anderson 2001) was used in order to test for temporal changes in bacterial assemblages (Factor 1: season, fixed with 2 levels = summer and winter; Factor 2: tide, fixed with 4 levels = high, low, flow and ebb; Factor 3: diurnal, fixed with 2 levels = night and day). A non-metric MDS analysis was used to visualise the temporal patterns in bacterial communities, and an analysis of the contribution of variables to similarity (SIMPER, Primer) was conducted to determine the OTU that best explained spatial differences only when spatial and temporal differences were found (Clarke \& Warwick 2001). Temperature was compared across seasons, diurnal and tidal cycles by a 3-way ANOVA. Effects and relative importance of individual constrained factors (diurnal cycle, tide and temperature within season) were assessed separately after removing the variance due to season using a unimodal partial correspondence analysis ( $\mathrm{pCCA}_{\text {; }}$ using $\mathrm{R})$.

Real-time PCR calculations were based on relative DNA concentration $(\Delta \mathrm{C}[\mathrm{t}])$ of vibrios based on lowest detected concentration (C[t]). Fold differences in Vibrio DNA template were calculated assuming 2-fold PCR reaction efficiency $\left(2^{\Delta C(t)}\right)$. One-way ANOVA (minitab) was used to compare between seasons.

\section{RESULTS}

\section{Spatial and temporal patterns in WBB abundances}

There was no significant difference in bacterial abundances between sites within both summer $(8 \pm 1$ $\times 10^{6}$ cells $\mathrm{ml}^{-1}$ recorded across all sites) and winter $\left(1.55 \pm 1 \times 10^{6}\right.$ cells ml $\left.^{-1}\right)$, which suggests that the influx of surrounding off-reef waters had little effect on total bacterial abundance at our sites (Fig. 2a). However, bacterial abundances showed a strong seasonal pattern (ANOVA $F=23.02$, df $=1, \mathrm{p}<0.001$ ), increasing by approximately 3 -fold during summer on the reef flat. Although there appeared to be a greater mean abundance during low tides compared to high tides and an apparent diurnal trend, where abundance increased from morning to afternoon within the summer season (Fig. 2b), this was not significant (ANOVA $F=1.29, \mathrm{df}=3, \mathrm{p}=0.293$ ).

\section{Spatial and temporal patterns in WBB diversity}

WBB diversity was significantly different between both seasons and time of day (PERMANOVA, $F=5.40$, $\mathrm{p}=0.001$ for seasons; $F=2.34, \mathrm{p}<0.002$ for diurnal) 


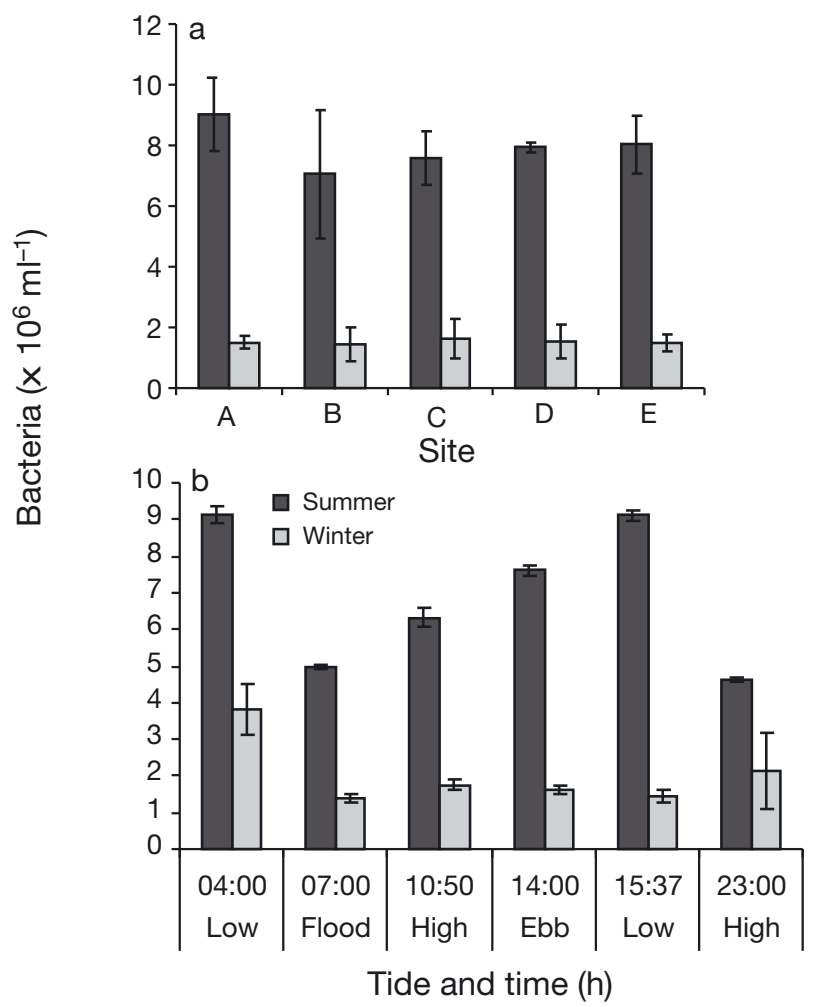

Fig. 2. Total bacterial abundance. (a) Spatial variation for 5 locations around Heron Island during winter (August 2008, light grey bars) and summer (March 2009, dark grey bars). A: Reef Flat, B: Coral Gardens, C: Lagoon, D: 3rd/4th Point, E: Wistari. (b) Temporal, tidal and diurnal variation on the reef flat for winter (August 2008, light grey bars) and summer (March 2009, dark grey bars). Error bars for both represent SE

but not for tide (PERMANOVA, $F=1.26, \mathrm{p}=0.063$ ). Bacterial diversity also showed significant interaction between season and diurnal cycles (PERMANOVA, $F=1.96, \mathrm{df}=1, \mathrm{p}=0.005$ ) but non-significant interaction between season and tidal cycles (Table 1, Fig. 3a). Between factors, season alone explained $14 \%$ of the variance whilst the significant interaction between time of day, tide and season explained a further $10.5 \%$ (Table 1). Over $40 \%$ of the total variance was explained by differences among replicates, which highlights the variable nature of WBB communities; pCCA with permutations stratified within seasons showed the percent variance of each factor with diurnal cycle effects being highly significant $(F=2.05$, p $<0.01)$, whilst both temperature (within each season) and tide were not significant $(F<1.1, \mathrm{p}>0.26)$. Average BrayCurtis similarity between summer and winter was $15 \%$, with different ribotypes from Alpha- and Gammaproteobacteria (Fig. 3b-d), Flavobacteria (Fig. 3e) and Bacteroidetes related ribotypes (Fig. 3f) explaining $38.5 \%$ of the dissimilarity (Table 2 ). Interestingly, differences in the bacterial community between night and day were more pronounced during winter compared to summer (Fig. 4). Since tides had no effect, this indicates that seasonality apparently has a greater effect on the composition of WBB communities than the benthic community that the water body has passed over, which in turn would be dependent on the state of the tide.

Significant interactions with temperature were found between seasons and the diurnal cycle (ANOVA, $F=6.2, \mathrm{df}=1,101 \mathrm{p}=0.01$ ) and between seasons and the tidal cycle (ANOVA, $F=4.43$, df $=2$, $101 \mathrm{p}=0.01$ ) (Fig. 5). This observation suggests that the effect of temperature is tied to the effects seen in diurnal and tidal patterns of WBB. Therefore, it is difficult to separate the effects of temperature alone as a potential environmental driver for WBB dynamics (Pommier et al. 2007, Fuhrman et al. 2008), and this was supported by the pCCA result, whereby the effect of temperature within seasons was not significant. However, the factors controlling the presence or absence of particular ribotypes (Alpha- and Gammaproteobacteria, Flavobacteria and Bacteroidetes related sequences) within summer and winter seasons deserves further investigation (Table 2, Fig. 3b,f).

Table 1. Three-way permutation analysis of variance (PERMANOVA) based on Euclidian distances. Significant differences shown in bold

\begin{tabular}{|lccccrr|r}
\hline Source & df & SS & MS & $F$ & p & Variance explained \\
\hline Diurnal & $\mathbf{1}$ & $\mathbf{7 7 6 9 . 8}$ & $\mathbf{7 7 6 9 . 8}$ & $\mathbf{2 . 3 4 0 6}$ & $\mathbf{0 . 0 0 2}$ & $\mathbf{7 . 6 8}$ \\
Tide & 3 & 12551 & 4183.6 & 1.2603 & 0.063 & 4.48 \\
Season & $\mathbf{1}$ & $\mathbf{1 7 9 2 6}$ & $\mathbf{1 7 9 2 6}$ & $\mathbf{5 . 4 0 0 1}$ & $\mathbf{0 . 0 0 1}$ & $\mathbf{1 3 . 9 1}$ \\
Diurnal $\times$ Tide & $\mathbf{3}$ & $\mathbf{1 4 8 2 8}$ & $\mathbf{4 9 4 2 . 8}$ & $\mathbf{1 . 4 8 9}$ & $\mathbf{0 . 0 0 5}$ & $\mathbf{8 . 6 9}$ \\
Diurnal $\times$ Season & $\mathbf{1}$ & $\mathbf{6 5 2 1 . 1}$ & $\mathbf{6 5 2 1 . 1}$ & $\mathbf{1 . 9 6 4 4}$ & $\mathbf{0 . 0 0 5}$ & $\mathbf{9 . 2 1}$ \\
Tide $\times$ Season & 3 & 11899 & 3966.2 & 1.1948 & 0.116 & $\mathbf{0 . 4 8}$ \\
Diurnal $\times$ Tide $\times$ Season & $\mathbf{3}$ & $\mathbf{1 3 5 2 0}$ & $\mathbf{4 5 0 6 . 6}$ & $\mathbf{1 . 3 5 7 6}$ & $\mathbf{0 . 0 1 7}$ & $\mathbf{1 0 . 5 1}$ \\
Residual & 97 & $3.22 \times 10^{5}$ & 3319.6 & & & 40.04 \\
Total & 112 & $4.13 \times 10^{5}$ & & & & \\
\hline
\end{tabular}



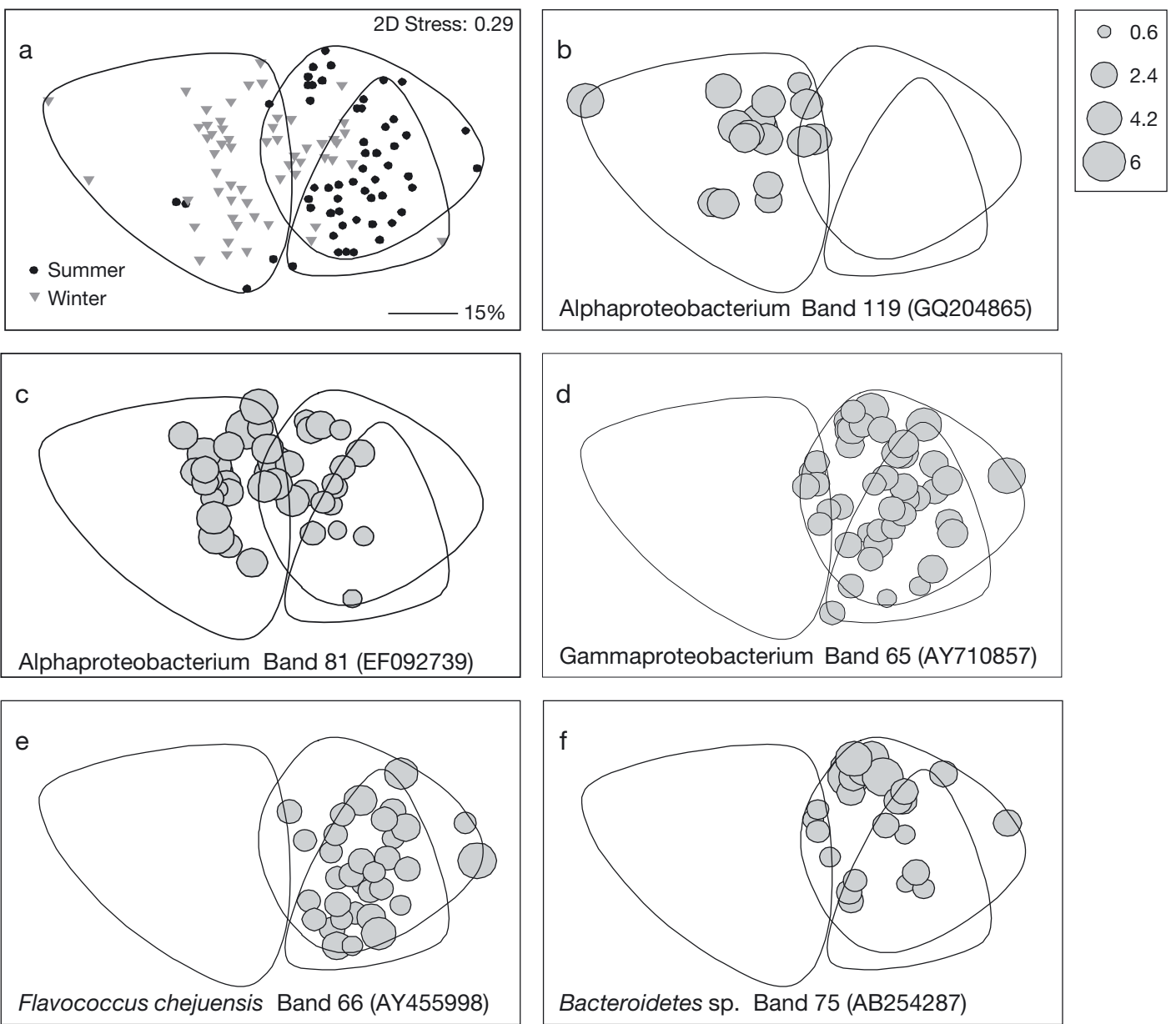

Fig. 3. (a) Multidimensional scaling (MDS) plot, showing seasonal changes in 16S rRNA gene profiles of bacterial communities. Each point represents an independent sample labelled by season (see key). (b-f) Relative abundances of a subset of specific bacteria present or absent within each sample that contributed to the similarities and differences seen within the seasonal and diurnal patterns. Bubble size represents relative density of the denaturing gradient gel electrophoresis (DGGE) band of that particular bacterial sequence within individual samples. Contour lines represent average Bray-Curtis similarity of $15 \%$

Real-time PCR showed no significant differences between total Vibrio DNA in summer and winter samples (ANOVA $F=0.58, p=0.457$ ). However, the mean was 1-fold higher in summer compared to winter (Fig. 6).

The composition of WBB communities varied across sites during both winter (ANOSIM, R $=0.48, \mathrm{p}=$ 0.001 ) and summer (ANOSIM, R $=0.57, \mathrm{p}=0.001$ ). However, pairwise comparisons showed significant differences only between the reef flat and the other sites both during winter (ANOSIM, p < 0.001) and summer (ANOSIM, p < 0.003), whilst other reef sites were not significantly different from each other (winter ANOSIM, p > 0.54 and summer ANOSIM, p > 0.1). Similarity of WBB between sites (based on BrayCurtis similarity) was $46 \%$ for winter samples and $47 \%$ for summer. Lagoon, off-reef and mixed (reef) sites had similar bacterial communities during the winter (Fig. 7a) and summer (Fig. 8a) showing no specific patterns of ordination or clustering except for that at the reef flat (Figs. $7 b$ \& 8b). The uniform lack of differences in the composition of WBB communities across sites with different levels of exposure to off-reef waters further supports the lack of tidal affects and indicates no significant association between the benthic and WBB communities. This is further supported, as the patterns were repeated in both seasons.

No significant differences were found between discrete bottle and continuous (1 h) pump sampling (ANOSIM, R $=0.07, \mathrm{p}=0.5$ ), indicating that discrete bottle sampling provides a representative sample of bacterial assemblages found within the larger water mass at any given time period. 
Table 2. Closest match (GenBank ID) and identification of bacterial taxa from the water column sequenced from denaturing gradient gel electrophoresis (DGGE) bands. Out of a total 143 operational taxonomic units (OTUs), 51 are represented in this table, which account for $70 \%$ of the variance between the 2 seasons (summer and winter). Relative abundance measurements are based on BioNumerics presence/absence and band intensity

\begin{tabular}{|c|c|c|c|c|c|c|}
\hline \multirow{2}{*}{$\begin{array}{l}\text { DGGE } \\
\text { band ID } \\
\text { (OTU) }\end{array}$} & \multirow{2}{*}{$\begin{array}{l}\text { Closest relative } \\
\text { (\% match) }\end{array}$} & \multirow[t]{2}{*}{ Taxon } & \multicolumn{2}{|c|}{ Abundance (band intensity) } & \multicolumn{2}{|c|}{ Average dissimilarity $86.6 \%$} \\
\hline & & & Summer & Winter & $\begin{array}{c}\text { Contribution } \\
(\%)\end{array}$ & $\begin{array}{c}\text { Accumulative } \\
\text { contribution }(\%)\end{array}$ \\
\hline 119 & GQ204865 (100) & Alphaproteobacteria & 0.34 & 1.61 & 2.52 & 2.52 \\
\hline 83 & & Unknown & 0.92 & 1.12 & 2.39 & 4.9 \\
\hline 74 & GQ204865 (98) & Alphaproteobacteria & 1.26 & 0.79 & 2.31 & 7.22 \\
\hline 65 & AY710857 (100) & Gammaproteobacteria & 1.45 & 0.45 & 2.3 & 9.52 \\
\hline 125 & & Unknown & 0.38 & 1.14 & 2.3 & 11.81 \\
\hline 112 & & Unknown & 0.74 & 1.12 & 2.01 & 13.82 \\
\hline 86 & & Unknown & 0.42 & 1.19 & 1.96 & 15.79 \\
\hline 118 & GQ204865 (97) & Alphaproteobacteria & 0.5 & 1.13 & 1.95 & 17.73 \\
\hline 104 & & Unknown & 0.94 & 0.53 & 1.76 & 19.49 \\
\hline 92 & EU005645 (78) & Gammaproteobacteria & 0.38 & 0.83 & 1.75 & 21.24 \\
\hline 66 & AY455998 (89) & Flavococcus chejuensis & 1.12 & 0.19 & 1.74 & 22.98 \\
\hline 127 & & Unknown & 0.23 & 0.93 & 1.74 & 24.72 \\
\hline 42 & AB254287 (98) & Bacteroidetes sp. & 0.93 & 0.24 & 1.7 & 26.42 \\
\hline 91 & GQ204865 (98) & Alphaproteobacteria & 0.77 & 0.54 & 1.63 & 28.05 \\
\hline 75 & AB254287 (100) & Bacteroidetes sp. & 0.91 & 0.32 & 1.63 & 29.69 \\
\hline 81 & EF092739 (95) & Alphaproteobacteria & 0.85 & 0.42 & 1.56 & 31.25 \\
\hline 126 & & Unknown & 0.18 & 0.85 & 1.55 & 32.8 \\
\hline 87 & GQ204834 (88) & Alphaproteobacteria & 0.55 & 0.62 & 1.45 & 34.25 \\
\hline 85 & FJ620860 (90) & Alphaproteobacteria & 0.43 & 0.76 & 1.43 & 35.68 \\
\hline 41 & FJ745255 (89) & Flavobacterium sp. & 0.73 & 0.14 & 1.24 & 36.92 \\
\hline 99 & FJ620860 (95) & Alphaproteobacteria & 0.54 & 0.45 & 1.24 & 38.16 \\
\hline 71 & EU600663 (100) & Flavobacteria sp. & 0.56 & 0.35 & 1.22 & 39.38 \\
\hline 90 & FJ620845 (83) & Alphaproteobacteria & 0.39 & 0.58 & 1.2 & 40.58 \\
\hline 115 & EF092824 (92) & Alphaproteobacteria & 0.35 & 0.61 & 1.2 & 41.78 \\
\hline 82 & & Unknown & 0.62 & 0.33 & 1.19 & 42.98 \\
\hline 111 & EU315614 (97) & Alphaproteobacteria & 0.4 & 0.48 & 1.19 & 44.16 \\
\hline 70 & AM989479 (95) & Tenacibaculum soleae & 0.35 & 0.51 & 1.18 & 45.35 \\
\hline 64 & AB294989 (100) & Flavobacteriales sp. & 0.56 & 0.41 & 1.18 & 46.53 \\
\hline 78 & EF092824 (92) & Alphaproteobacteria & 0.58 & 0.41 & 1.18 & 47.7 \\
\hline 120 & & Unknown & 0.13 & 0.66 & 1.16 & 48.86 \\
\hline 110 & AB254277 (83) & Cyanobacteria & 0.31 & 0.57 & 1.13 & 50 \\
\hline 46 & EU315645 (88) & Gammaproteobacteria & 0.68 & 0.15 & 1.1 & 51.1 \\
\hline 95 & EF486532 (95) & Alphaproteobacteria & 0.36 & 0.52 & 1.1 & 52.19 \\
\hline 114 & FJ620845 (87) & Alphaproteobacteria & 0.3 & 0.57 & 1.09 & 53.28 \\
\hline 116 & EU600663 (77) & Flavobacteria sp. & 0.42 & 0.41 & 1.08 & 54.37 \\
\hline 128 & & Unknown & 0.16 & 0.52 & 1.07 & 55.43 \\
\hline 113 & & Unknown & 0.18 & 0.57 & 1.05 & 56.49 \\
\hline 63 & AJ784117 (78) & Eubacterium sp. & 0.3 & 0.49 & 1.01 & 57.49 \\
\hline 129 & & Unknown & 0.16 & 0.48 & 1 & 58.49 \\
\hline 58 & EU984467 (81) & Bacterium & 0.41 & 0.36 & 0.98 & 59.47 \\
\hline 84 & GQ250615 (89) & Alphaproteobacteria & 0.17 & 0.58 & 0.97 & 60.45 \\
\hline 67 & GQ257639 (82) & Gammaproteobacteria & 0.62 & 0.06 & 0.97 & 61.41 \\
\hline 102 & & Unknown & 0.37 & 0.39 & 0.96 & 62.37 \\
\hline 106 & & Unknown & 0.5 & 0.21 & 0.96 & 63.33 \\
\hline 109 & & Unknown & 0.5 & 0.12 & 0.94 & 64.27 \\
\hline 97 & FJ532499 (100) & Alphaproteobacteria & 0.52 & 0.2 & 0.93 & 65.2 \\
\hline 89 & & Unknown & 0.08 & 0.54 & 0.88 & 66.08 \\
\hline 121 & & Unknown & 0.13 & 0.46 & 0.86 & 66.94 \\
\hline 122 & & Unknown & 0.33 & 0.24 & 0.85 & 67.79 \\
\hline 117 & & Unknown & 0.28 & 0.34 & 0.85 & 68.64 \\
\hline 69 & DQ656191 (95) & Bacteroidetes sp. & 0.44 & 0.18 & 0.85 & 69.48 \\
\hline 108 & AM748242 (84) & SAR 11 (Pelagibacter ubique) & e) 0.26 & 0.37 & 0.84 & 70.32 \\
\hline
\end{tabular}



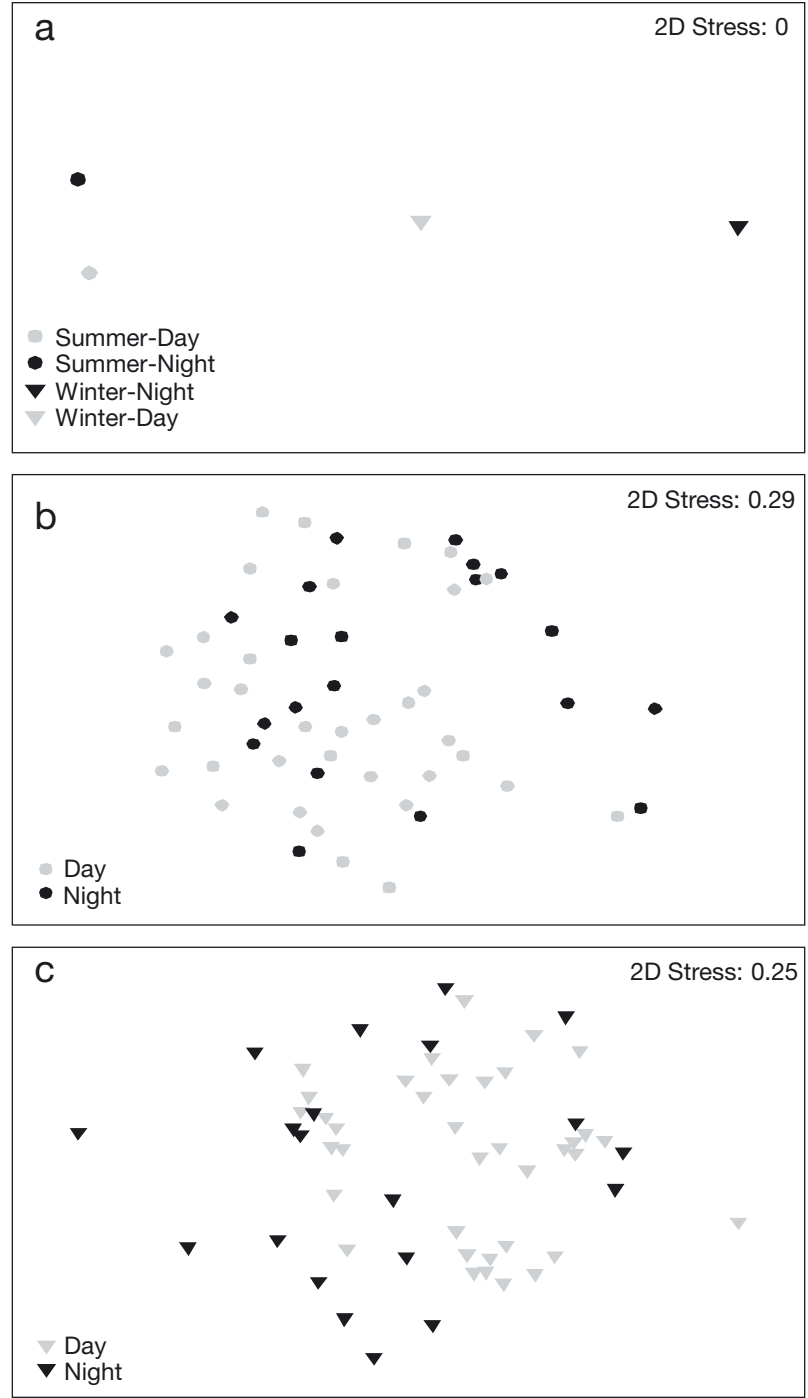

Fig. 4. Multidimensional scaling (MDS) plot, showing diurnal changes in bacterial communities (16S rRNA gene fingerprints) on the reef flat between seasons. (a) Mean of samples for summer day $(\mathrm{n}=37)$, summer night $(\mathrm{n}=20)$, winter day $(\mathrm{n}=35)$, winter night $(\mathrm{n}=20)$. (b) All samples for the winter season. (c) All samples for the summer season

\section{DISCUSSION}

Benthic marine communities are physically exposed to, and presumably influenced by, the delivery of bacteria present in the overlying water column. On coral reefs, coral surface mucus layers and seawater have been shown to share certain bacterial species (Ritchie 2006, Sunagawa et al. 2010). Conversely, Wild et al. (2004) have shown a significant supply of coral-derived mucus and its associated bacterial communities to the water column (Wild et al. 2004, 2005, 2009, Naumann
Tide $x$ Season: $F=4.43, \mathrm{p}=0.01$

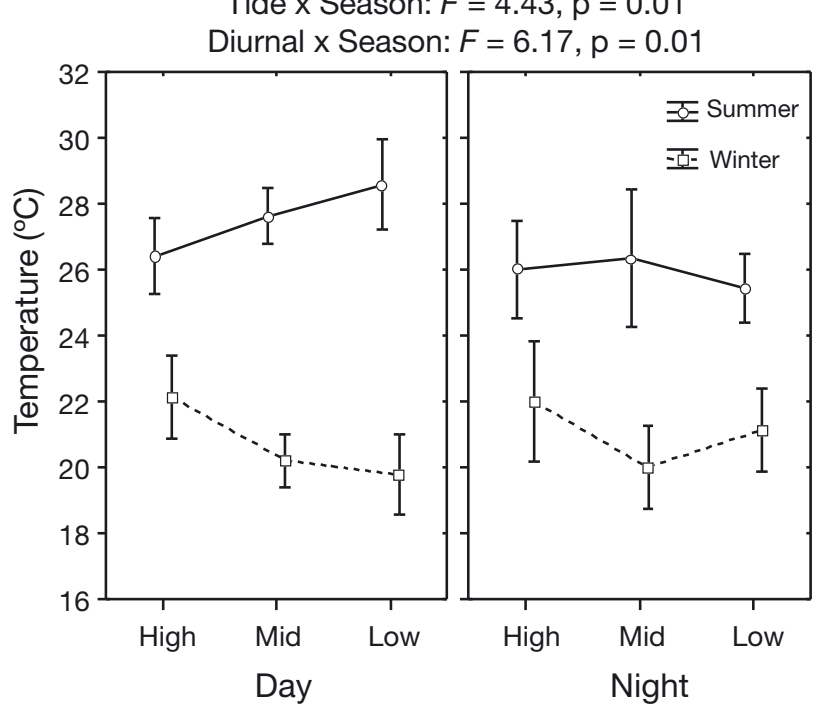

Fig. 5. Sea temperatures at Heron Island collected using a Hobo ${ }^{\circledR}$ (Onset Computer Corporation) data logger, showing seasonal, tidal and diurnal patterns. Results of a PERMANOVA showing significant interactions with temperature between season and diurnal cycles and between season and tidal cycles are included in the figure. Error bars show SE

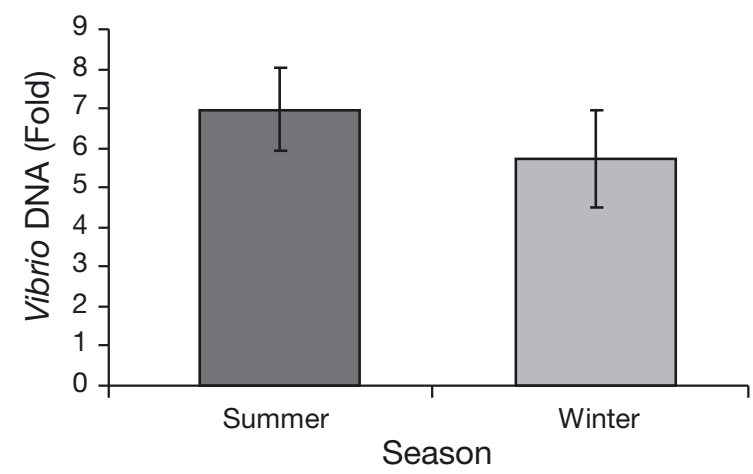

Fig. 6. Total relative Vibrio DNA present within 10 representative random samples from each season (summer and winter), acquired from real-time PCR (see 'Materials and methods'). $Y$-axis represents total Vibrio DNA within each sample (standardised to total DNA concentration before PCR of $50 \mathrm{ng}$ reaction $^{-1}$ ), shown as fold differences based on lowest concentrations detected within the samples $(n=20)$. Error bars represent $\mathrm{SE}$ from collective mean

et al. 2009). At Heron Island, Wild et al. (2004) showed that up to ca. $1.7 \mathrm{l} \mathrm{m}^{-2} \mathrm{~d}^{-1}$ of mucus is released from the reef into the water column and biodegraded in lagoon sediments. Thus, there is likely to be significant bidirectional exchange between the coral reef benthos and the water column. However, in this study, we found no evidence that the WBB communities differed depending on the underlying benthos. In fact, with the exception of a reef flat site, WBB communities ap- 
a

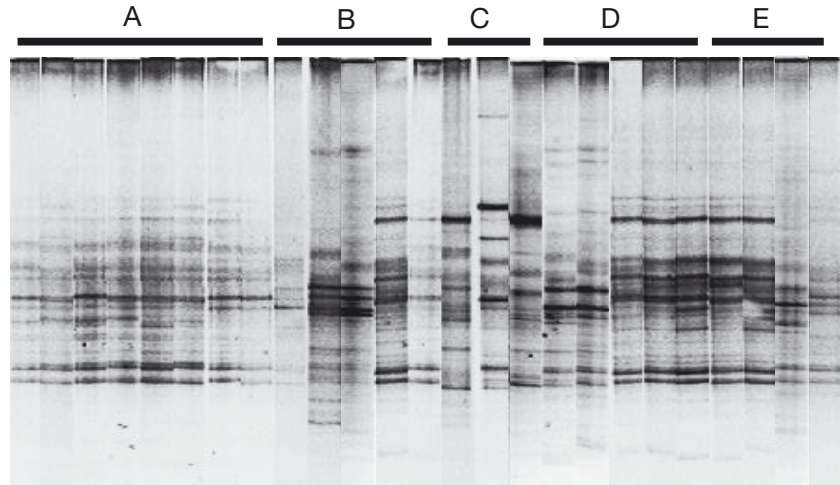

b

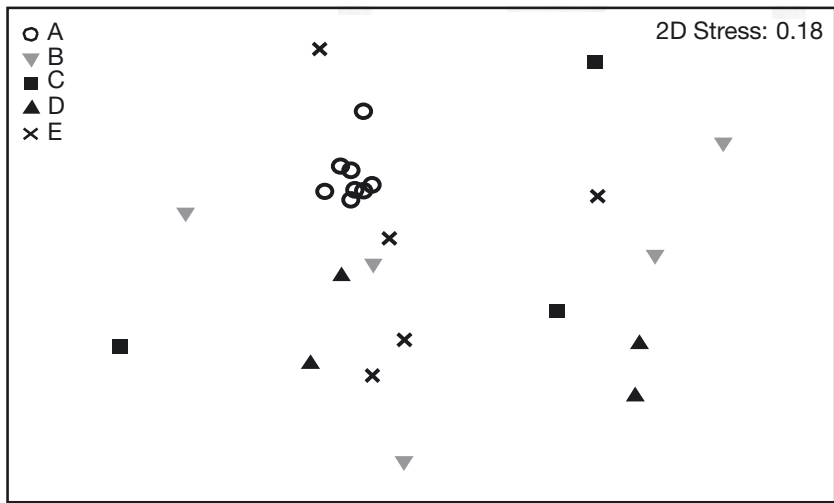

Fig. 7. Variation in 16S rRNA gene fingerprints between sites (A-E) for August 2008 (winter). (a) Composite denaturing gradient gel electrophoresis (DGGE) image standardised for gel-to-gel comparison using BioNumerics. (b) Multidimensional scaling (MDS) plot based on relative band intensity from composite DGGE profile (a). Overall similarity between samples $=46 \%$. See Fig. 2 for site identifications

peared homogeneous between sites, despite the fact that the water bodies sampled would have originated from very different environments, including lagoonal, reef and off-reef open water areas. Previous studies have shown significant differences in WBB across sites (Moriarty et al. 1985, Seymour et al. 2005, Guppy \& Bythell 2006, Ritchie 2006). However, few studies have controlled for tide height, season and time of day when assessing spatial differences in the reef tract. Lack of differences in bacterial abundances and diversity between sites could in part be explained by the spatial scale chosen in this study. While temporal samples showed some short-term (hours) variability, spatial patterns were determined from samples separated by 100s of metres to kilometres within the Heron Island reef system. Thus, it is possible that spatial variation in bacterial communities may be greater at smaller $(<1 \mathrm{~m})$ spatial scales (van Duyl \& Gast 2001, Seymour et al. 2005) and that this smaller-scale variation masked any larger-scale variation.

If the benthic-pelagic coupling described by Wild et al. (2004) was a slow process, one would have ex-

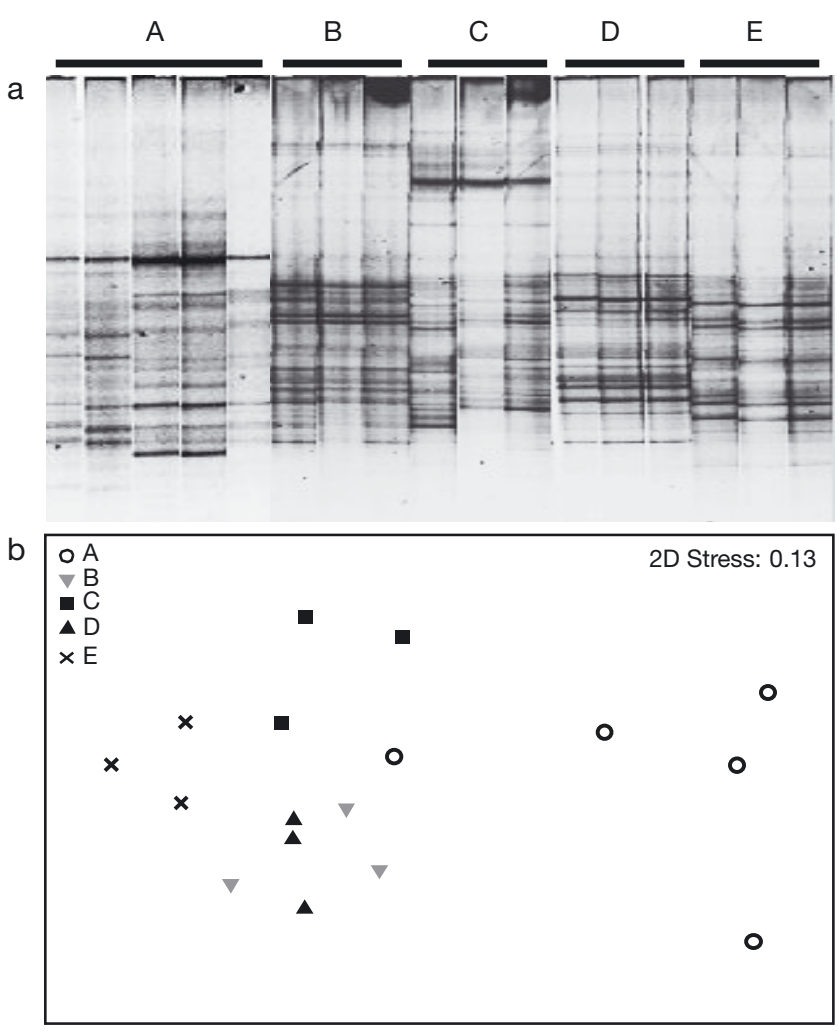

Fig. 8. As in Fig. 7, but for March 2009 (summer)

pected significant differences in both numbers and diversity between sites, especially those sites where the water mass was from reef flats and the lagoon compared to water originating from off-reef in more open water. As pairwise tests showed no significant difference between sites (except for that of the reef flat), we suggest that the benthic-pelagic coupling occurring at Heron Island is a rapid process with large-scale, efficient mixing of the water column and the benthic coral system.

As has been shown in a number of studies (Kent et al. 2004, 2007, Pommier et al. 2007, Fuhrman et al. 2008, Shade et al. 2008), the main factor affecting bacterial abundances and 16S rRNA gene diversity is season. In these studies, temperature was shown to be the main factor affecting bacterial species richness. Fuhrman et al. (2008) showed a consistent latitudinal pattern in seasonality, which was annually repeatable and highly predictable from a variety of environmental parameters. Whilst Fuhrman et al. (2008) showed no correlation between WBB dynamics and productivity, WBB could also be affected by other seasonal environmental drivers (e.g. nutrients, irradiance, precipitation). In our study, we found that bacterial abundance was 4 to 5 times greater in summer than winter, suggesting that bacterial productivity is higher in summer, most likely due to temperature differences (Moriarty et al. 1985). Shade et al. (2008) 
also found that temporal variation of bacterial diversity and abundance within fresh-water habitats was more pronounced than spatial variation, but they attributed their temporal differences to interactions and changes within phytoplankton communities.

During winter, ribotypes from the Alphaproteobacteria dominated WBB communities. Ribotypes associated with this group have been consistently found associated with healthy coral tissues (Ritchie \& Smith 2002). During summer months, ribotypes from the Gammaproteobacteria were present in higher abundances but were either completely absent or rare in the winter samples. Optimal growth temperatures for both Gamma- and Alphaproteobacteria range from 20 to $40^{\circ} \mathrm{C}$ (Brettar et al. 2002, 2003, Santos et al. 2003, Kurahashi \& Yokota 2007, Anderson et al. 2009). However, these variations in temperature are largely species specific, not group specific, so growth rates of specific groups would not explain these result alone. Real-time PCR showed that the abundance of Vibrio (a genus known to contain potential coral pathogens; Kushmaro et al. 2001, Ben-Haim et al. 2003, Rosenberg \& Falkovitiz 2004) did not vary significantly between seasons, although the mean was a fold higher in summer than winter. These results together indicate that potentially pathogenic bacteria may increase in abundance during warmer months, and therefore opportunistic infections may become more frequent and explain at least some of the concomitant increase in disease prevalence in summer (Jones et al. 2004), although future work is needed to confirm these patterns.

Despite the strong tidal flows on Heron Island and therefore large-scale interactions with reef, lagoonal and open water environments, there was no significant effect of tide state on WBB abundance or 16S rRNA gene diversity. Significant diurnal variation was observed, however, and differences in bacterial abundance between night and day were stronger during the winter than in the summer. The greater variation seen during diurnal rather than tidal cycles on this reef system supports a previous study (Moriarty et al. 1985), which linked bacterial growth to the daily mucus release on the reef flats, which normally occurs between noon and 16:00 $\mathrm{h}$ regardless of the tide (Crossland et al. 1980, Torreton \& Dufour 1996). Other possible explanations for the diurnal dynamics of WBB communities include overall productivity and/or the interaction between diurnal zooplankton migrations between the benthos and the water column (Heidelberg et al. 2010), given that these zooplankton will have their own microbiota associated with them directly and may alter bacterial production due to excretion and secretion.

The continuous sampling method and large sample size used in this study was investigated to determine whether it would provide a more accurate characterisation of bacterial communities within the water column. We conclude that although discrete sampling is adequate to represent the WBB communities, the use of pump sampling is a more repeatable method, and a larger sample size can be taken at any given time. In addition, human errors and potential contamination during collection and handling of samples that may be incurred during bottle sampling can be reduced with this continuous in situ method.

Acknowledgements. This work was supported by the Natural Environmental Research Council, UK (NE/E006949). We thank the staff at Heron Island Research Station, Australia, for their support and cooperation in the field; O. Pantos, University of Queensland, for help with logistics and field sampling; and T. Taybi, Newcastle University, for technical support.

\section{LITERATURE CITED}

Anderson MJ (2001) A new method for non-parametric multivariate analysis of variance. Austral Ecol 26:32-46

- Anderson CR, Dick GJ, Chu ML, Cho JC, Davis RE, Brauer SL, Tebo BM (2009) Aurantimonas manganoxydans, sp. nov. and Aurantimonas litoralis, sp. nov.: Mn(II) oxidizing representatives of a globally distributed clade of alphaProteobacteria from the order Rhizobiales. Geomicrobiol J 26:189-198

Ben-Haim Y, Thompson FL, Thompson CC, Cnockaert MC, Hoste B, Swings J, Rosenberg E (2003) Vibrio coralliilyticus sp. nov., a temperature-dependent pathogen of the coral Pocillopora damicornis. Int J Syst Evol Microbiol 53:309-315

> Brettar I, Christen R, Hofle MG (2002) Rheinheimera baltica gen. nov., sp. nov., a blue-coloured bacterium isolated from the central Baltic Sea. Int J Syst Evol Microbiol 52: 1851-1857

Brettar I, Christen R, Hofle MG (2003) Idiomarina baltica sp. nov., a marine bacterium with a high optimum growth temperature isolated from surface water of the central Baltic Sea. Int J Syst Evol Microbiol 53:407-413

Clarke KR, Warwick RM (2001) A further biodiversity index applicable to species lists: variation in taxonomic distinctness. Mar Ecol Prog Ser 216:265-278

Crossland CJ, Barnes DJ, Borowitzka MA (1980) Diurnal lipid and mucus production in the staghorn coral Acropora acuminata. Mar Biol 60:81-90

Crossland CJ, Hatcher BG, Atkinson MJ, Smith SV (1984) Dissolved nutrients of a high-latitude coral reef, Houtman Abrolhos Islands, Western Australia. Mar Ecol Prog Ser 14:159-163

- Fuhrman JA, Steele JA, Hewson I, Schwalbach MS, Brown MV, Green JL, Brown JH (2008) A latitudinal diversity gradient in planktonic marine bacteria. Proc Natl Acad Sci USA 105:7774-7778

Gourlay MR, Hacker JLF (2008) Technical Report: Reef-top currents in vicinity of Heron Island boat harbour, Great Barrier Reef, Australia: 1. Overall influence of tides, winds and waves. Hydraulic Model Report CH Series CH72/08, School of Engineering, The University of Queensland, Brisbane

Guppy R, Bythell JC (2006) Environmental effects on bacterial diversity in the surface mucus layer of the reef coral Montastraea faveolata. Mar Ecol Prog Ser 328:133-142 
Heidelberg KB, O'Neil KL, Bythell JC, Sebens KP (2010) Vertical distribution and diel patterns of zooplankton abundance and biomass at Conch Reef, Florida Keys (USA). J Plankton Res 32:75-91

> Jones RJ, Bowyer J, Hoegh-Guldberg O, Blackall LL (2004) Dynamics of a temperature-related coral disease outbreak. Mar Ecol Prog Ser 281:63-77

Kent AD, Jones SE, Yannarell AC, Graham JM, Lauster GH, Kratz TK, Triplett EW (2004) Annual patterns in bacterioplankton community variability in a humic lake. Microb Ecol 48:550-560

Kent AD, Yannarell AC, Rusak JA, Triplett EW, McMahon KD (2007) Synchrony in aquatic microbial community dynamics. ISME J 1:38-47

Kurahashi M, Yokota A (2007) Endozoicomonas elysicola gen. nov., sp nov., a gamma-proteobacterium isolated from the sea slug Elysia ornata. Syst Appl Microbiol 30:202-206

Kushmaro A, Banin E, Loya Y, Stackebrandt E, Rosenberg E (2001) Vibrio shiloi sp. nov., the causative agent of bleaching of the coral Oculina patagonica. Int J Syst Evol Microbiol 51:1383-1388

Ludington CA (1979) Tidal modifications and associated circulation in a platform reef lagoon. Aust J Mar Freshw Res 30:425-430

> Moriarty DJW, Pollard PC, Hunt WG (1985) Temporal and spatial variation in bacterial production in the water column over a coral reef. Mar Biol 85:285-292

Moses CS, Andréfouët S, Kranenburg CJ, Muller-Karger FE (2009) Regional estimates of reef carbonate dynamics and productivity using Landsat 7 ETM+, and potential impacts from ocean acidification. Mar Ecol Prog Ser 380:103-115

> Muyzer G, Dewaal EC, Uitterlinden AG (1993) Profiling of complex microbial populations by denaturing gradient gel electrophoresis analysis of polymerase chain reactionamplified genes coding for 16s ribosomal RNA. Appl Environ Microbiol 59:695-700

- Naumann MS, Richter C, el-Zibdah M, Wild C (2009) Coral mucus as an efficient trap for picoplanktonic cyanobacteria: implications for pelagic-benthic coupling in the reef ecosystem. Mar Ecol Prog Ser 385:65-76

Paul JH, DeFlaun MF, Jeffrey WH (1986) Elevated levels of microbial activity in the coral surface microlayer. PSZN I Mar Ecol 33:29-40

Pommier T, Canback B, Riemann L, Boström KH and others (2007) Global patterns of diversity and community structure in marine bacterioplankton. Mol Ecol 16:867-880

Ritchie KB (2006) Regulation of microbial populations by coral surface mucus and mucus-associated bacteria. Mar Ecol Prog Ser 322:1-14

Ritchie KB, Smith GW (2004) Microbial communities of coral surface mucopolysaccharide layers. In: Rosenburg E, Loya $\mathrm{Y}$ (eds) Coral health and disease. Springer Verlag, Berlin, p 259-263

Rosenberg E, Falkovitiz L (2004) The Vibrio shiloi/Oculina patagonica model system of coral bleaching. Annu Rev Microbiol 58:143-159

Sanchez O, Gasol JM, Massana R, Mas J, Pedros-Alio C (2007) Comparison of different denaturing gradient gel electrophoresis primer sets for the study of marine bacterioplankton communities. Appl Environ Microbiol 73:5962-5967

Santos P, Pinhal I, Rainey FA, Empadinhas N and others (2003) Gamma-proteobacteria Aquicella lusitana gen. nov., sp nov., and Aquicella siphonis sp. nov. infect protozoa and require activated charcoal for growth in laboratory media. Appl Environ Microbiol 69:6533-6540

Selinummi J, Seppala J, Yli-Harja O, Puhakka JA (2005) Soft- ware for quantification of labeled bacteria from digital microscope images by automated image analysis. BioTechniques 39:859-863

> Seymour JR, Patten N, Bourne DG, Mitchell JG (2005) Spatial dynamics of virus-like particles and heterotrophic bacteria within a shallow coral reef system. Mar Ecol Prog Ser 288: $1-8$

Shade A, Jones SE, McMahon KD (2008) The influence of habitat heterogeneity on freshwater bacterial community composition and dynamics. Environ Microbiol 10: 1057-1067

Siboni N, Lidor M, Kramarsky-Winter E, Kushmaro A (2007) Conditioning film and initial biofilm formation on ceramics tiles in the marine environment. FEMS Microbiol Lett 274:24-29

Somerville CC, Knight IT, Straube WL, Colwell RR (1989) Simple, rapid method for direct isolation of nucleic acids from aquatic environments. Appl Environ Microbiol 55: $548-554$

Sorokin YI (1973) On the feeding of some scleractinian corals with bacteria and dissolved organic matter. Oceanography 18:380-385

Sorokin YI (1974) Bacteria as a component of the coral reef community. In: Cameron AM, Cambell BM, Cribb AB, Endean R and others (eds) Proc 2nd Int Symp Coral Reefs, Vol 1, June 22-July 2, 1973. The Great Barrier Reef Committee, Brisbane, p 3-10

Sunagawa S, Woodley CM, Medina M (2010) Threatened corals provide underexplored microbial habitats. PLoS ONE 5:e9554, doi: 10.1371/journal.pone.0009554

Thompson JR, Randa MA, Marcelino LA, Tomita-Mitchell A, Lim E, Polz MF (2004) Diversity and dynamics of a north Atlantic coastal Vibrio community. Appl Environ Microbiol 70:4103-4110

Torréton JP, Dufour P (1996) Temporal and spatial stability of bacterioplankton biomass and productivity in an atoll lagoon. Aquat Microb Ecol 11:251-261

van Duyl FC, Gast GJ (2001) Linkage of small-scale spatial variations in DOC, inorganic nutrients and bacterioplankton growth with different coral reef water types. Aquat Microb Ecol 24:17-26

Weinbauer MG, Beckmann C, Hofle MG (1998) Utility of green fluorescent nucleic acid dyes and aluminum oxide membrane filters for rapid epifluorescence enumeration of soil and sediment bacteria. Appl Environ Microbiol 64: 5000-5003

Wild C, Huettel M, Klueter A, Kremb SG, Rasheed MYM, Jergensen BB (2004) Coral mucus functions as an energy carrier and particle trap in the reef ecosystem. Nature 428 : 66-70

Wild C, Woyt H, Huettel M (2005) Influence of coral mucus on nutrient fluxes in carbonate sands. Mar Ecol Prog Ser 287: $87-98$

Wild C, Naumann MS, Haas A, Struck U, Mayer FW, Rasheed MY, Huettel M (2009) Coral sand $\mathrm{O}_{2}$ uptake and pelagic-benthic coupling in a subtropical fringing reef, Aqaba, Red Sea. Aquat Biol 6:133-142

Yamaguchi N, Baba T, Nakagawa S, Saito A, Nasu M (2007) Rapid monitoring of bacteria in dialysis fluids by fluorescent vital staining and microcolony methods. Nephrol Dial Transplant 22:612-616

Yu W, Dodds WK, Banks MK, Skalsky J, Strauss EA (1995) Optimal staining and sample storage time for direct microscopic enumeration of total and active bacteria in soil with two fluorescent dyes. Appl Environ Microbiol 61: 3367-3372

Submitted: December 22, 2009; Accepted: June 15, 2010

Proofs received from author(s): August 4, 2010 